\title{
Disease infection by Enterobacteriaceae family in fishes: A review
}

\begin{abstract}
Enterobacteriaceae family microorganisms are the major cause of infection in humans. Usually, they are commonly found in normal microbiota from fish. The incorrect handling of professionals that work with fish farm, and the indiscriminate use of antibiotics in the pisciculture can lead to the onset of diseases in fishes transmittable to human consumer.
\end{abstract}

Keywords: Enterobacteriaceae, fish infection, pisciculture
Volume 4 Issue 5 - 2017

\author{
Renato Ventresqui Oliveira,' Monica Costa \\ Oliveira, ${ }^{2}$ Afonso Pelli' \\ 'Federal University of Triangulo Mineiro, Brazil \\ ${ }^{2}$ Medical veterinary, City hall of Altinopolis, Brazil
}

Correspondence: Afonso Pelli, Professor Av. Frei Paulino, 300 Uberaba, MG, Brazil ,Tel +55 343700 6424,

Email apelli@terra.com.br

Received:September 12, 2016 | Published: May 02, 2017

\section{Introduction}

Fish farming has increased in the last decades, in order to the growth of animal protein consumption. The food safe handling is a topic widely discussed in various studies that discussed the migration of microorganisms exclusive from fish to human feed. Enterobacteriaceae family is one group, which includes the most species related with infection in humans. Microorganisms of Enterobacteriaceae family are Gram-negatives, positives for catalase, facultative aerobics and non-glucose fermenters. ${ }^{1}$ These microorganisms are usually found in gastrointestinal tract from fish, but a study performed by. ${ }^{2}$ showed that microorganisms like Escherichia coli, Enterobacter spp. and Klebsiela pneumoniae., ${ }^{3-5}$ are frequently isolated from fish in pisciculture.

The presence of Enterobacteriaceae bacteria in fish farming lead to a serious health public risk. Despite in most cases these microorganisms are part of normal microbiota from fish, when colonizing human sites, they can cause some diseases, like urinary tract infection. ${ }^{6}$ For preventing infection on fish and economic loss, ${ }^{7}$ the use of antibiotics in aquaculture has been widely used, ${ }^{6,8}$ but the indiscriminate use of these drugs has led to the emergence of resistant strains, a very dangerous situation for the consumers. ${ }^{9}$ Isolation of Enterobacteriaceae species has been the focus of researches, especially in fish farming, due to the transmission of resistant bacteria to humans. ${ }^{10}$

In a research performed by Peixoto et al.. ${ }^{4}$, Pseudomonas aeruginosa and Enterobacter cloacae were isolated from curimba, Prochilodus lineatus (Valenciennes, 1837) in a closed system. The fish exhibited the following descriptions: adult member with $42.69 \mathrm{~mm}$ total length and $31.96 \mathrm{~mm}$ length pattern. The fish had the following infectious processes: bleeding in the pectoral fin, ulceration head above the eyes. Oliveira et al. $^{3}$, isolated strains of Klebsiella penumoniae from a nishikigoi carp, Cyprinus carpio Linnaeus, 1758, in a closed system vivarium. In this case report, the authors observed lesion of necrosis, but no systemic infection was observed. Escherichia coli are the most frequent microorganism isolated in fish meal and water in fish farming. Ristori et al. ${ }^{11}$ investigated the presence of $E$. coli $\mathrm{O} 157: \mathrm{H} 7$ in fish meal, in order to prevent the transmission to the consumers.
Conceição et al. ${ }^{12}$ investigate the presence of microorganism in fish farming at Conceição das Alagoas, Minas Gerais - Brazil, and Enterobacteriaceae the most isolated species were from Enterobacteriaceae family. Yagoub. ${ }^{2}$ isolated Enteriobacteriaceae family and Pseudomonas spp. from fresh fish bought in supermarket (Tilapia nilotica Linn). Among the bacteria from Enterobacteriaceae family, $23.2 \%$ of the strains isolated were identified as $E$. coli. The authors point out the need that the experimental and theoretical methods must be done like described in Nascimento et al. ${ }^{13}$.

Since several of these microorganisms are transmitted by fecaloral route as observed with contaminated fruits or vegetables, the risk to human health may be during handling, processing or, where it is difficult to determine the source of the microbes. When it occurs during handling, a hypothesis that could be raised could probably be the reflection of the use of bovine manure to stimulate the production of plankton in nursery. The authors point out the need of eliminates the use of manure in all systems, especially when in direct contact with fish or fish farmers.

\section{Conclusion}

Bacteria from Enterobacteriaceae family are present in the normal fish microbiota, but some as E. coli, Klebsiella penumoniae and Pseudomonas spp. can cause human diseases. The indiscriminate use of antibiotic in fish farming has led to the emergent of resistant strains that in contact with the consumer can lead to several health problems. We already know the consequences of indiscriminate use of antibiotics can lead, but despite this, even today we are not able to deal with the biodiversity of natural systems. For avoiding this imbalance, we must recognize this scenery and go further than this limitation that will help to understand the natural systems, the interactions between microorganisms, with their hosts and with the environment. Thus, the balance between host, environment and the desired food security would be established.

\section{Acknowledgements}

The authors thank UFTM and CEMIG by the financial support. 


\section{Conflicts of interest}

There is no conflict of interest.

\section{Funding}

None.

\section{References}

1. Kaper JB, Nataro JP, Mobley HL. Pathogenic Escherichia coli. Nat Rev Microbiol. 2004;2(2):123-140.

2. Yagoub SO. Isolation of Enterobacteriaceae and Pseudomonas spp. from raw fish sold in fish market in Khartoum state. J Bacteriol Res. 2009;1(7):85-88.

3. Oliveira RV, Peixoto PG, Ribeiro DC, et al. Klebsiella pneumoniae as a main cause of infection in nishikigoi Cyprinus carpio (carp) by inadequate handling. Brazilian J Vet Pathol. 2014;7(2):86-88.

4. Peixoto PG, Oliveira RV, Silva BB, et al. Isolamento de Pseudomonas aeruginosa e Enterobacter cloacae isolados em curimba Prochilodus lineatus em sistema fechado. Iniciação Científica Cesumar. 2013;15(2):189-191.

5. Guzmán MC, De Los Angeles Bistoni M, Tamagnini LM, et al. Recovery of Escherichia coli in fresh water fish, Jenynsia multidentata and Bryconamericus iheringi. Water Res. 2004;38(9):2367-2373.

6. Nagamatsu K, Hannan TJ, Guest RL, et al. Dysregulation of Escherichia coli $\alpha$-hemolysin expression alters the course of acute and persistent urinary tract infection. Proc Natl Acad Sci USA. 2015;112(8):E871-880.
7. Oliveira RV, Peixoto PG, Conceição N, et al. Colimetria de ambientes aquáticos com cultivo de jaú, Zungaro jahu em Conceição das Alagoas/ Minas Gerais. J Health Sci Inst. 2014;2(1):82-85.

8. Romero J, Feijoó CG, Navarrete P. Antibiotics in Aquaculture-Use, Abuse and Alternatives. Health and Environment in Aquaculture. $2012 ; 160-198$.

9. Gastalho S, Silva GJ, Ramos F. Uso de antibióticos em aquacultura e resistência bacteriana: Impacto em saúde pública. Acta Farm Port. 2014;3(1):29-45.

10. Elsherief M, Mousa MM, ElGalil A, et al. Enterobacteriaceae associated with farm fish and retailed ones. Alexandria J Vet Sci. 2014;42(1):99104.

11. Ristori CA, Iaria ST, Gelli DS, et al. Pathogenic bacteria associated with oysters (Crassostrea brasiliana) and estuarine water along the south coast of Brazil. Int J Environ Health Res. 2007;17(4):259-269.

12. Conceição N, Oliveira AG, Oliveira RV, et al. Variação espacial e sazonal de microrganismos associados ao cultivo do Zungaro jahu (Ihering, 1898), na Estação Ambiental de Volta Grande no Estado de Minas Gerais. (Spatial and seasonal variation of microorganisms associated with the cultivation of Zungaro jahu (Ihering, 1898) at the Volta Grande Environmental Station in the State of Minas Gerais.) J Heal Sci Inst. 2012;30(2):186-190.

13. Nascimento LL, Conceição Natália, Silva Paulo Roberto da, et al. Padronização de procedimentos para coleta e semeadura de microorganismos em ambientes aquáticos neotropicais mesotróficos. Revista UNINGÁ Review. 2012;12(1):54-57. 